\title{
Bir devlet hastanesi üçüncü basamak çocuk yoğun bakım ünitesinde çoklu ilaç dirençli gram negatif enfeksiyonların değerlendirilmesi
}

\author{
Evaluation of multidrug-resistant gram-negative infections in a state hospital tertiary \\ care pediatric intensive care unit
}

\author{
Fulya Kamit, Dicle Şener
}

Gönderilme tarihi:15.02.2020

Kabul tarihi:11.05.2020

\begin{abstract}
Özet
Amaç: Devlet hastanesi üçüncü basamak çocuk yoğun bakım ünitemizde saptanan çoklu ilaç dirençli (ÇiD) gram negatif bakteriyel enfeksiyonların ve ilaç dirençlerinin değerlendirilmesi amaçlanmıştır.

Gereç ve yöntem: Denizli Devlet Hastanesi Çocuk Yoğun Bakım Ünitesinde Ocak 2017-Eylül 2019 tarihleri arasında yatııılarak tedavi edilen ve alınan kültürlerinde ÇiD gram negatif bakteriyel üreme saptanan hastaların tıbbi kayıtları geriye dönük olarak değerlendirildi.

Bulgular: Toplamda 40 hastanın (ortanca yaş: 30 ay; $17 \mathrm{kız}$ ), 48 çocuk yoğun bakım yatışında, klinik olarak anlamlı kabul edilen 52 ÇiD gram negatif bakteriyel üreme değerlendirildi. Hastaların en sık yatış nedeni solunum yetmezliği $(\% 39,5)$, en sık komorbidite nörolojik/nöromüsküler hastalıktı $(\% 57,5)$ ve 16 hasta trakeostomiliydi (\%40). Çalışma süresince 4 hasta kaybedildi. En sık tespit edilen ÇiD bakteriler P.aeruginosa (16 vaka), E.coli (13 vaka), K.pneumoniae (13 vaka) ve A.baumannii (10 vaka) idi. En sık saptanan enfeksiyon tipleri, ventilatör ilişskili pnömoni ve idrar yolu enfeksiyonuydu. Toplamda 34 vaka $(\% 65,3)$ sağlık hizmeti ilişkili enfeksiyon olarak değerlendirildi. Karbapenem direnci P.aeruginosa'da \%69, K.pneumoniae'da \%69, A.baumannii'de \%100 bulunurken, E.coli'de karbapenem direnci saptanmadı. On yedi vakada kolistin kombinasyonları, 19 vakada karbapenem ve kombinasyonları kullanıldı. Trakeostomiye bağı solunum yolu enfeksiyonu tespit edilen 9 vakanın yedisi P.aeruginosa kaynaklıydı. Karbapenem direnci bulunan 25 ÇiD üremenin 10'u trakeostomili hastalarda saptanmıştı. Trakeostomi varlığı ile karbapenem direnci arasında istatistiksel olarak anlamlı ilişki saptanmadı $(p>0,05)$. Vakaların hepsinde son 3 ayda antibiyotik kullanımı vardı. Öncesinde kullanılan antibiyotik tipi ile karbapenem direnci arasında istatistiksel olarak anlamlı ilişki saptanmadı $(p>0,05)$.

Sonuç: Yoğun bakımlarda ÇiD gram negatif bakteri enfeksiyonları giderek artmaktadır. Bu mikroorganizmalarla oluşan enfeksiyonlar açısından etkin kontrol ve önleme politikalarına intiyaç vardır.
\end{abstract}

Anahtar kelimeler: Çoklu ilaç direnci, gram negatif bakteri, sağlık hizmeti ilişkili enfeksiyon, çocuk yoğun bakım, trakeostomiye bağlı solunum yolu enfeksiyonu.

Kamit F, Şener D. Bir devlet hastanesi üçüncü basamak çocuk yoğun bakım ünitesinde çoklu ilaç dirençli gram negatif enfeksiyonların değerlendirilmesi. Pam Tıp Derg 2020;13:547-554.

\begin{abstract}
Purpose: It was aimed to evaluate the multiple drug resistant (MDR) gram-negative bacterial infections and antimicrobial drug resistance in our state hospital tertiary pediatric intensive care unit (PICU).

Materials and methods: Medical records of patients, who had MDR gram-negative bacterial isolates from their specimens, admitted to Denizli State Hospital PICU between January 2017 and September 2019 were retrospectively evaluated.

Results: A total of $52 \mathrm{MDR}$ gram-negative bacterial isolates causing infections that were collected from 40 children (median age: 30 months; 17 girls) with $48 \mathrm{PICU}$ admissions were evaluated. The most common cause of PICU admission was respiratory failure (39.5\%), most common comorbidity was neurological/neuromusculary disease $(57.5 \%)$ and 16 patients had tracheostomy $(40 \%)$. Four patients died in the study period. The most common causative agents were P.aeruginosa (16 cases), E.coli (13 cases), K.Pneumoniae (13 cases) and A.baumannii (10 cases). A total of 34 cases were considered as health care associated infection $(65.3 \%)$. Nonsusceptibility to carbapenems in P. aeruginosa, K.pneumoniae and A.baumannii were found $69 \%, 69 \%$ and $100 \%$,respectively, while none of the isolates were carbapenem resistant in E.coli. Colistin and combinations were used in 17 cases, while carbapenem and combinations used in 19 cases. P.aeruginosa was the causative agent in 7 cases of 9 tracheostomy associated respiratory infections. Of $25 \mathrm{MDR}$ isolates, 10 were detected from patients with tracheostomy. There was no significant relationship between the presence of tracheostomy and carbapenem resistance $(p>0.05)$. All of the cases used antibiotics in the last 3 months. There was no statistically significant relationship between the type of antibiotic used before and carbapenem resistance $(p>0.05)$.
\end{abstract}

Fulya Kamit, Dr. Denizli Devlet Hastanesi, Çocuk Sağlığı ve Hastalıkları, Yoğun Bakım Ünitesi, Denizli, Türkiye, e-posta: fulyakamit@yahoo. co.uk (orcid.org/0000-0003-1078-9781) (Sorumlu Yazar)

Dicle Şener, Uzm. Dr. Denizli Devlet Hastanesi, Çocuk Enfeksiyon Hastalıkları Polikliniği Denizli, Türkiye, e-posta: diclesen71@yahoo.com (orcid.org/0000-0002-1170-2185) 
Conclusion: MDR gram negative bacterial infections are gradually increasing in intensive care units. Effective control and prevention policies are needed for infections caused by these microorganisms.

Key words: Multi-drug resistant, gram negative organisms, health care associated infections, pediatric intensive care unit, tracheostomy-associated respiratory infections.

Kamit F, Sener D. Evaluation of multidrug-resistant gram-negative infections in a state hospital tertiary care pediatric intensive care unit. Pam Med J 2020;13:547-554.

\section{Giriş}

Ülkemizde ve dünyada doksanlı yıllardan itibaren gram negatif bakteriyel patojenlerde antimikrobiyal direncin arttığı bildirilmektedir [1-4]. Çoklu ilaç dirençli (ÇiD) bakteriyel enfeksiyonların, günümüzde sağlık hizmeti ilişkili enfeksiyonlar (SHIE) olarak tanımlanan nozokomiyal enfeksiyonların \%20'sini aştığı tahmin edilmektedir [5, 6]. Özellikle ÇiD gram negatif bakteriler için halen kısıtlı tedavi seçeneği olduğundan, bu durum hasta sonuçlarını kötüleştiren ve her yıl büyüyen ciddi bir klinik problem haline gelmiştir $[5,6]$.

Yoğun bakımlardaki ÇiD bakteriyel ajan sıklık ve çeşitliliği ülkeler, coğrafi bölgeler ve üniteler arasında değişkenlik gösterir. Her yoğun bakım ünitesinin kendine has antimikrobiyal direnç özellik ve trendinin bilinmesi bu bakteriyel ajanlarla oluşan enfeksiyonların yönetim başarısı ve en nihayetinde hasta sonuçlarının iyileştirilmesi için elzemdir [2, 3, 7-10].

Biz de çalışmamızda Denizli Devlet Hastanesi üçüncü basamak çocuk yoğun bakım ünitemizde ÇíD gram negatif bakteriyel enfeksiyonları ve antimikrobiyal ilaç dirençlerini değerlendirmeyi amaçladık.

\section{Gereç ve yöntem}

Çocuk yoğun bakım ünitemizde, üçüncü basamak 6 yatak mevcut olup, 1 ay-18 yaş arası kritik çocuk hastalar izlenmektedir. Ünitemizde bir adet izolasyon odası bulunmaktadır. Yirmi dört saat boyunca aktif hasta kabul, tedavi ve bakımı yapılmakta olup, hasta-hemşire oranı 2:1, nöbet şartlarında 3:1'dir. Hastaların tedavi yönetimi nöbetçi çocuk sağlığı ve hastalıkları uzmanı ve sorumlu çocuk yoğun bakım uzmanı tarafından, dirençli enfeksiyonların tedavi kararı ise çocuk enfeksiyon hastalıkları uzmanı konsültasyonuyla yapılmaktadır. Yatırılarak izlenen hasta sayısı yıllık ortalama 350'dir. Ünitemizde enfeksiyon kontrol ve önleme ölçütleri "Hastalık Kontrol ve Önleme Merkezi" kılavuzlarına göre uygulanmakta ve hastanemiz "Enfeksiyon Kontrol Komitesi" görevli hemşiresi ve çocuk enfeksiyon hastalıkları uzmanı tarafından aktif sürveyans yapılmaktadır [11]. Sorumlu çocuk yoğun bakım uzmanı tarafından örnek alınma endikasyonu konulan vakalardan kan, idrar, vücut sıvıları ve diğer çeşitli materyallerden alınan tüm numuneler, standart mikrobiyolojik prosedürlere uygun alınmakta ve işlenmektedir [12].

Çalışmada Denizli Devlet Hastanesi Çocuk Yoğun Bakım Ünitesinde Ocak 2017-Eylül 2019 tarihleri arasında yatırılarak tedavi edilen enfeksiyon şüphesi ile alınmış klinik materyallerden izole edilen ve klinik olarak anlamlı kabul edilmiş çiD gram negatif bakteriyel üremeleri saptanan, 1 ay-18 yaş çocuk hastaların tıbbi kayıtları (yaş, cinsiyet, çocuk yoğun bakım giriş tanısı, çocuk yoğun bakım yatış süresi, komorbidite, enfeksiyon tipi, kullanılan antibiyotik tipi, son üç aydaki antibiyotik kullanımı, uygulanmış alet-araçlar, hastanın sonucu) ve saptanan Çỉ gram negatif bakterilerin özellikleri (bakterinin türü, üreme bölgesi, diğer üreme özellikleri, antibiyotik direnç özellikleri) hasta dosyası ve bilgisayar sisteminden geriye dönük olarak kaydedilmiştir. Klinik örneklerin ekim işleminde $\% 5$ koyun Kanlı Agar (RTA, Türkiye) ve Eozin Metilen Blue (RTA, Türkiye) besiyerleri kullanılmıştır. Ekimi yapılan örnekler $37^{\circ} \mathrm{C}$ 'de $18-24$ saat inkübe edildikten sonra değerlendirilmiştir. Bakteri türlerinin tanımlanmasında ve bakterilerin antibiyotik duyarlılığının belirlenmesinde Vitek2 (BioMérieux, Fransa) otomatize sistemleri kullanılmış ve antibiyotik duyarlılıkları "The European Commitee on Antimicrobial Susceptibility Testing (EUCAST)" kriterlerine göre yorumlanmıştır.

Bu çalışma için etik onayı, İzmir Demokrasi Üniversitesi Girişimsel Olmayan Klinik Araştırmalar Etik Kurulu'ndan alınmıştır. 
Trakeostomiye bağlı solunum yolu enfeksiyonu (TBSYE), trakeostomi ile birlikte bakteriyel pnömoni, aspirasyon pnömonisi veya bakteriyel trakeit tanılarının birlikteliği olarak tanımlanmıştır [13]. SHİE, ventilatör ilişkili pnömoni (VIP), santral venöz katater ilişkili kan akımı enfeksiyonu (SVKIKAE), semptomatik idrar yolu enfeksiyonu (SIYE) olarak sınıflandırılmış ve SHIE tanısı ve tanımlamaları "Centers for Disease Control and Prevention (CDC)" kriterlerine göre değerlendirilmiştir [14]. TBSYE tanımlaması CDC kriterlerine göre "pnömoni dışı alt solunum yolu enfeksiyonu" ve "pnömoni" tanılarına karşılık gelmektedir. En az 3 antimikrobiyal kategoriden birer ajana karşı direnç varlığı "ÇİD” olarak tanımlanmıştır [15].

Tüm veriler SPSS 16.0 istatistik programında yapılmıştır. Kategorik veriler sayı (n) ve yüzde (\%) ile ifade edilirken, rakamsal veriler ortanca ile belirtilmiştir. Kategorik verilerin değerlendirilmesinde ki-kare, rakamsal verilerin değerlendirilmesinde ise Mann-Whitney $U$ testleri kullanılmış ve $p<0,05$ istatistiksel olarak anlamlı kabul edilmiştir.

\section{Bulgular}

Çocuk yoğun bakım ünitesine Ocak 2017-Eylül 2019 tarihleri arasında 882 hasta yatırıldı. Çalışma süresinde 168 gram negatif bakteriyel üreme tespit edildi. Toplamda 40 hastanın (ortanca yaş: 30 ay; 17 kız), 48 çocuk yoğun bakım yatışında, klinik olarak anlamlı kabul edilen 52 Çỉ gram negatif bakteriyel üreme değerlendirildi.

Hastaların en sık yatış nedeni solunum yetmezliği $(\% 39,5)$, en sık komorbidite nörolojik/nöromüsküler hastalıktı $(\% 57,5)$ ve 16 hasta trakeostomiliydi (\%40). Vakaların hepsinde son 3 ayda antibiyotik kullanımı vardı. Çalışma süresince 4 hasta kaybedildi (Tablo 1). Kaybedilen 2 hastada ölüm nedeni geçirdiği enfeksiyona bağlı septik şok ve çoklu organ yetmezliği, diğer ikisinde ise altta yatan hastalıklarının hızla ilerlemesiydi.
En sık tespit edilen Çì gram negatif bakteriler P.aeruginosa (16 vaka, \%30,7), E.coli (13 vaka, \%25), K.pneumoniae (13 vaka, \%25) ve A.baumannii (10 vaka,\%19,2) idi (Şekil 1).

En sık saptanan enfeksiyon tipleri, VIP ve SIYE idi. Toplamda 34 vaka $(\% 65,3)$ SHIE olarak değerlendirildi (Tablo 2). En sık SHIE nedeni VIP $(20, \% 50)$ ve üretilen bakteriler P.aeruginosa (7 vaka), A.baumannii (7 vaka), K.pneumoniae (7 vaka) idi. Tespit edilen 9 bakteriyel TBSYE'nun çoğunluğu P.aeruginosa kaynaklıydı (7 vaka). İki hastada SiYE ve VIP, 1 hastada VIP ve SVKIKAE, 1 hastada VIP, SIYE ve SVKIKAE birlikte gelişmişti. Üç hastada aynı SHİE atağında aynı bölgede çoklu gram negatif bakteri üremesi oldu. SHİE vakalarının 22'sinde santral venöz katater, 20'sinde üriner kateter mevcuttu, 5 hasta total parenteral beslenme alıyordu. Bu hastaların 6'sı immunsuprese, 5'i trakeostomili idi.

Karbapenem direnci P.aeruginosa'da \%69, K.pneumoniae'da \%69, A.baumannii'de \%100 bulunurken, E.coli'de karbapenem direnci saptanmadı(Tablo3). P.aeruginosaüremelerinde piperasilin-tazobaktam ve seftazidim direnci $\% 87,5$ iken, amikasin direnci \%31 idi. On yedi vakada kolistin kombinasyonları, 19 vakada karbapenem ve kombinasyonları kullanıldı.

Karbapenem direnci bulunan toplam 25 çỉD gram negatif üremenin 10'u (\%40) trakeostomili hastalarda saptanmıştı. Trakeostomisi olan (10/25, \%40) ve olmayan (15/25, \%60) hastalardaki karbapenem direnci karşılaştırıldığında, trakeostomi varlığı ile karbapenem direnci arasında istatistiksel olarak anlamlı ilişki saptanmadı $(p>0,05)$.

Son 3 ayda kullanılan antibiyotik tipi ile karbapenem direnci karşılaştırıldığında; karbapenem direnci saptanan üremelerde son 3 ayda sefalosporin kullanımı \%58, karbapenem kullanımı \%33, amikasin kullanımı \%4 idi. Son 3 ayda kullanılan antibiyotik tipi ile karbapenem direnci arasında istatistiksel olarak anlamlı ilişki saptanmadı $(p>0,05)$ 
Tablo 1. Hastaların klinik ve demografik özellikleri

\begin{tabular}{|c|c|}
\hline Toplam hasta sayısı & 40 \\
\hline Çocuk yoğun bakıma yatış sayısı & 48 \\
\hline Yaş (ay) (ortanca, min-max) & $30(3-192)$ \\
\hline Cinsiyet (K) (n/\%) & $17(42,5)$ \\
\hline $\begin{array}{l}\text { Uyruk (n/\%) } \\
\text { TC } \\
\text { Suriye }\end{array}$ & $\begin{array}{r}33(82,5) \\
7(17,5)\end{array}$ \\
\hline $\begin{array}{l}\text { Altta yatan hastalık (n/\%) } \\
\text { Nörolojik/nöromüsküler } \\
\text { Genetik } \\
\text { Solunum } \\
\text { Kardiyak } \\
\text { Nefrolojik } \\
\text { İmmunolojik } \\
\text { Yok }\end{array}$ & $\begin{aligned} 23 & (57,5) \\
5 & (12,5) \\
4 & (10) \\
2 & (5) \\
2 & (5) \\
1 & (2,5) \\
3 & (7,5)\end{aligned}$ \\
\hline $\begin{array}{l}\text { Giriş tanısı (n/\%) } \\
\text { Solunum yetmezliği } \\
\text { Sepsis/septik şok } \\
\text { Status epileptikus } \\
\text { Postresüsitasyon } \\
\text { Travma }\end{array}$ & $\begin{array}{l}19(39,5) \\
15(31,2) \\
10(20,8) \\
2(4,1) \\
2(4,1)\end{array}$ \\
\hline Trakeostomili hasta $(\mathrm{n} / \%)$ & $16(40)$ \\
\hline İmmunsuprese hasta (n/\%) & $6(15)$ \\
\hline Tekrarlayan hastane yatışı olan hasta (n/\%) & $24(60)$ \\
\hline $\begin{array}{l}\text { Son } 3 \text { ayda antibiyotik kullanımı (\%) } \\
\text { Var } \\
\text { Sefalosporin } \\
\text { Karbapenem } \\
\text { Aminoglikozit }\end{array}$ & $\begin{array}{l}100 \\
73 \\
21 \\
6\end{array}$ \\
\hline Çocuk yoğun bakım yatış günü (ortanca,min-max) & $21(4-65)$ \\
\hline Eksitus (n) & $4(10)$ \\
\hline
\end{tabular}

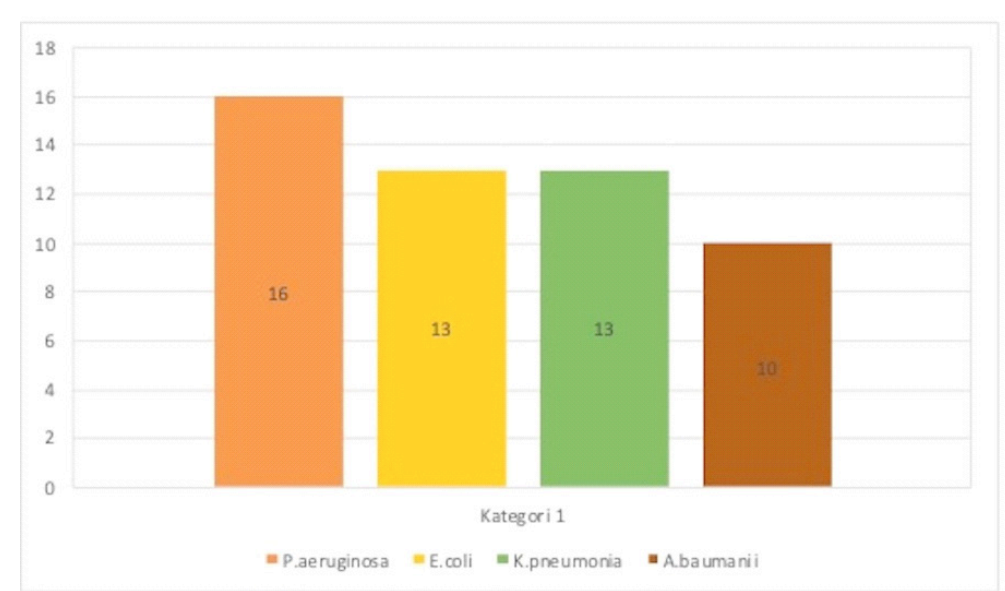

Şekil 1.Üretilen çoklu ilaç dirençli gram negatif bakteriler 
Tablo 2. Çoklu ilaç dirençli gram negatif enfeksiyonların klinik özellikleri

\begin{tabular}{|c|c|c|c|c|c|}
\hline Enfeksiyon Tipi & Toplam sayı & P.aeruginosa & E.coli & K.pneumoniae & A.baumannii \\
\hline $\begin{array}{l}\text { VIP } \\
\text { SIYE } \\
\text { TBSYE } \\
\text { SVKIKAE }\end{array}$ & $\begin{array}{l}20 \\
19 \\
9 \\
4\end{array}$ & $\begin{array}{l}7 \\
1 \\
7 \\
1\end{array}$ & $\begin{array}{l}- \\
11 \\
1 \\
1\end{array}$ & $\begin{array}{l}6 \\
6 \\
- \\
1\end{array}$ & $\begin{array}{l}7 \\
1 \\
1 \\
1\end{array}$ \\
\hline SHIE & 34 & 9 & 6 & 10 & 9 \\
\hline $\begin{array}{l}\text { Çoklu üremeler } \\
\text { (farklı bölge) } \\
\text { VIP+SIYE } \\
\text { VIP+SVKIKAE } \\
\text { VIP+SIYE+SVKIKAE }\end{array}$ & $\begin{array}{l}2 \\
1 \\
1\end{array}$ & 2 & 1 & $\begin{array}{l}1 \\
1\end{array}$ & 1 \\
\hline $\begin{array}{l}\text { Çoklu üremeler } \\
\text { (aynı bölge) } \\
\text { ViP } \\
\text { SiYY }\end{array}$ & $\begin{array}{l}2 \\
1\end{array}$ & $\begin{array}{l}2 \\
1\end{array}$ & - & $\begin{array}{l}2 \\
1\end{array}$ & - \\
\hline
\end{tabular}

VIP: Ventilatör iliş̧kili pnömoni; SIYE: Semptomatik idrar yolu enfeksiyonu;

TBSYE: Trakeostomiye bağlı solunum yolu enfeksiyonu; SVKIKAE: Santral venöz katater ilişkili kan akımı enfeksiyonu; SHIE: Sağlık hizmeti ilişkili enfeksiyon

Tablo 3. Üretilen gram negatif bakterilerin antimikrobiyal direnç özelliği

\begin{tabular}{|c|c|c|c|c|c|c|}
\hline & Meropenem & Seftazidim & Sefepim & Amikasin & Pip-Taz & TMP-SMX \\
\hline $\begin{array}{l}\text { P.aeruginosa } \\
\mathrm{n}=16\end{array}$ & $\begin{array}{l}\text { S:5 (\%31) } \\
\text { R/l:11 (\%69) }\end{array}$ & $\begin{array}{l}\text { S:2 }(\% 12,5) \\
\text { R/l:14 }(\% 87,5)\end{array}$ & $\begin{array}{l}\text { S:2 }(\% 12,5) \\
\text { R/l:14 }(\% 87,5)\end{array}$ & $\begin{array}{l}\text { S:11 (\%69) } \\
\text { R/l:5 (\%31) }\end{array}$ & $\begin{array}{l}\text { S:2 }(\% 12,5) \\
\text { R/l:14 }(\% 87,5)\end{array}$ & $\begin{array}{l}\text { S:6 }(\% 37,5) \\
\text { R/l:10 }(\% 62,5)\end{array}$ \\
\hline $\begin{array}{l}\text { E.coli } \\
n=13\end{array}$ & $\begin{array}{l}\text { S:13 (\%100) } \\
\text { R/l:0 (0) }\end{array}$ & $\begin{array}{l}\text { S:1 }(\% 7,5) \\
\text { R/l:12 (\%92,5) }\end{array}$ & $\begin{array}{l}\text { S:1 }(\% 7,5) \\
\text { R/l:12 }(\% 92,5)\end{array}$ & $\begin{array}{l}\text { S:6 (\%46) } \\
\text { R/l:7 (\%54) }\end{array}$ & $\begin{array}{l}\text { S:1 }(\% 7,5) \\
\text { R/l:12 (\%92,5) }\end{array}$ & $\begin{array}{l}\text { S:2 }(\% 15,5) \\
\text { R/l:11 }(\% 84,5)\end{array}$ \\
\hline $\begin{array}{l}\text { K.pneumonia } \\
n=13\end{array}$ & $\begin{array}{l}\text { S:9 (\%69) } \\
\text { R/l:4 (\%31) }\end{array}$ & $\begin{array}{l}\text { S:1 }(\% 7,5) \\
\text { R/l:12 (\%92,5) }\end{array}$ & $\begin{array}{l}\text { S:0 (0) } \\
\text { R/l:13 (\%100) }\end{array}$ & $\begin{array}{l}\text { S:6 (\%46) } \\
\text { R/l:7 (\%54) }\end{array}$ & $\begin{array}{l}\text { S:1 }(\% 7,5) \\
\text { R/l:12 (\%92,5) }\end{array}$ & $\begin{array}{l}\text { S:6 (\%46) } \\
\text { R/l:7 (\%54) }\end{array}$ \\
\hline $\begin{array}{l}\text { A.baumannii } \\
\qquad \mathrm{n}=10\end{array}$ & $\begin{array}{l}\text { S:0 (0) } \\
\text { R/l:10 }(\% 100)\end{array}$ & $\begin{array}{l}\text { S:0 (0) } \\
\text { R/l:10 } \\
(\% 100)\end{array}$ & $\begin{array}{l}\text { S:0 (0) } \\
\text { R/l:10 } \\
(\% 100)\end{array}$ & $\begin{array}{l}\text { S:0 (0) } \\
\text { R/l:10 } \\
(\% 100)\end{array}$ & $\begin{array}{l}\text { S:0 (0) } \\
\text { R/l:10 } \\
(\% 100)\end{array}$ & $\begin{array}{l}\text { S:4 (\%40) } \\
\text { R/l:6 }(\% 60)\end{array}$ \\
\hline
\end{tabular}

S: Duyarlı; R: Dirençli; I: Orta duyarlı; Pip-taz: Piperasilin-Tazobaktam; TMP-SMX: Trimetoprim-Sulfametoksazol

\section{Tartışma}

Gram negatif bakteriyel patojenlere antimikrobiyal direncin artması, tedavide kısıtlı seçeneklerin olması, antibiyotik direncinde lokal ve bölgesel değişkenlik nedeniyle, optimum antibiyotik kullanımı ve hasta sonuçları için her ünitenin kendi sürveyansını izlemesi ve değerlendirmesi çok önemlidir [1-10].

Bir devlet hastanesi üçüncü basamak çocuk yoğun bakım ünitesi olan servisimizde yaptığımız 2,5 yıllık bu çalışmada, tespit edilen toplam 168 gram negatif negatif üremenin yaklaşık \%30'u ÇìD idi. En sık saptanan ÇỉD gram negatif patojenler P.aeruginosa, E.coli, K.pneumoniae ve A.baumannii, en sık enfeksiyon tipi ise VIP idi. Ülkemizde bir üniversite hastanesinde çocuk hastalarda gram negatif enfeksiyonların değerlendirildiği bir çalışmada, ÇỉD vakaların \%38'i olup çalışmamızda aynı 4 etken en sık olarak bildirilmiştir [2]. Durdu ve ark'nın [1] İstanbul'da erişkin yoğun bakım ünitelerinde gram negatif enfeksiyonları değerlendirdiği çok merkezli çalışmada, yine en sık A.baumannii, Klebsiella türleri, P.aeruginosa ve E.coli saptanmıştır. Ülkemiz ve Mısır'dan çocuk yoğun bakım servisinde gram negatif enfeksiyonların değerlendirildiği iki çalışma da aynı etkenler ve VIP bizim çalışmamızdaki gibi en sık olarak belirtilmiştir [16, 17].

Çalışmamızda en sık saptanan patojen P.aeruginosa'da meropenem direnci \%69, piperasilin-tazobaktam ve seftazidim direnci \%87,5 iken, en duyarlı olduğu antimikrobiyal ajan amikasin idi (\%69). A. baumannii tüm suşları meropenem dirençli iken, E.coli'de meropenem 
direnci saptanmadı. ÇID bu izolatların hiçbirinde kolistin direnci görülmedi. En sık VIP etkenleri de P.aeruginosa ve A.baumannii idi. Ülkemizde üçüncü basamak çocuk yoğun bakım ünitesinde yapılan bir çalışmada da bizim çalışmamıza benzer şekilde VİP etkenleri en sık P.aeruginosa ve A.baumannii olarak saptanmış ve P.aeruginosa'da meropenem direnci $\% 65$, piperasilin-tazobaktam direnci \%76 bulunmuştur. Bizim sonuçlarımızdan farklı olarak amikasin direnci daha yüksek (\%65) bildirilmiştir. Yine tüm suşlar kolistin duyarlı olmakla birlikte, meropenem direnci en yüksek etken A.baumannii olarak belirtilmiştir (\%93) [6]. Ülkemizde erişkin yoğun bakımda yapılan bir çalışmada ise en sık VIP etkenleri aynı, P.aeruginosa'daimipenemveseftazidimeyüksek direnç, en duyarlı antimikrobiyal ajan amikasin olarak bildirilmiştir [18]. Almanya yoğun bakım ünitelerinde ÇíD gram negatif patojenlerde karbapenem direncinin değerlendirildiği çok merkezli çalışmada, en sık saptanan üç patojen de aynı olup, karbapenem direnci toplamda \%16 bulunmuştur. Antimikrobiyal direnç oranları direkt karşılaştırılabilir olmasa da Avrupa'daki direnç oranlarının ülkemizdeki değerlere göre oldukça düşük olduğu görülmüştür [19].

Çalışma süresince değerlendirilen hastaların \%90'ından fazlasının kronik bir hastalığı mevcuttu. En sık altta yatan hastalık nörolojik/nöromüsküler hastalıktı ve hastaların \%40'ı trakeostomili idi. Tekrarlayan hastane yatışlarının sık görüldüğü trakeostomili hasta grubunda, bunun en önemli nedeni P.aeruginosa'ya bağlı TBSYE idi. Russell ve ark.'nın [20, 21] Amerika'da çocuk yoğun bakım ünitelerinde yaptığı çok merkezli çalışmalarda, çalışmamızla uyumlu olarak trakeostomili çocuklarda en sık yatış nedeninin bakteriyel TBSYE olduğu, tekrarlayan yatışlarda en sık tespit edilen bakterinin $P$. aeruginosa ve en sık komorbiditenin de nöromüsküler hastalık olduğu bildirilmiştir. Trakeostomili hastaların yatışlarında P.aeruginosa'ya karşı ampirik başlanan antibiyotik tedavilerinin dirençli organizmaların artışında etkili olabileceği belirtilmiştir [21]. Fakat, biz trakeostomi varlığı ile karbapenem direnci arasında istatistiksel olarak anlamlı bir ilişki saptayamadık. Ayrıca TBSYE tanım ve yönetiminin kanıta dayalı rehberlerde bulunmaması, bu özellikli hasta grubunun sonuçlarını kötü yönde etkilediğini düşünmekteyiz.
Daha önce karbapenem kullanımının VIP haricindeki karbapenem dirençli gram negatif enfeksiyonların gelişiminde önemli faktör olduğu bildirilmiştir [22]. Çalışmamızda vakaların hepsi son 3 ayda antibiyotik kullanmıştı ve bunların \%33'ü karbapenem idi. Fakat son 3 ayda kullanılan antibiyotik tipi ile karbapenem direnci arasında istatistiksel olarak anlamlı bir ilişki saptayamadık. Bu sonucun çalışmamızda solunum yolu enfeksiyonlarının diğer enfeksiyonlardan daha yüksek oranda görülmesi ile ilişkili olabileceğini düşünmekteyiz.

Buçalışmanınbaşlıcakısıtılıklarıgeriyedönük ve tek merkezli bir çalışma olmasıyla birlikte, son dönemde ÇiD bakterilerin sınıflandırılmasında kullanılan ve bu yüksek antimikrobiyal dirence sahip bakterilerin sürveyansının doğru şekilde karşılaştırılabilmesini sağlayan terminolojinin (pan-drug rezistan, ekstrem drug rezistan) çalışmamızda kullanılamamasıdır.

Sonuç olarak, yoğun bakımlarda ÇỉD gram negatif bakteri enfeksiyonları giderek artmaktadır. Yoğun bakım ünitelerinin hem bölgesel hem de ülke genelinde çok merkezli çalışmalarla verilerini paylaşması, kısıtlı tedavi seçeneğinin olduğu dirençli enfeksiyonların kontrolünde ve önlenmesinde çok kıymetli olacaktır.

Çıkar ilişkisi: Yazarlar çıkar ilişkisi olmadığını beyan eder.

\section{Kaynaklar}

1. Durdu B, Kritsotakis EI, Lee ACK, et al. Temporal trends and patterns in antimicrobial-resistant gram-negative bacteria implicated in intensive care unit-acquired infections: a cohort-based surveillance study in Istanbul, Turkey. J Glob Antimicrob Resist 2018;14:190-196. https://doi.org/10.1016/j.jgar.2018.04.015

2. Aykac K, Ozsurekci Y, Tanır Basaranoglu S, et al. Current epidemiology of resistance among gramnegative bacilli in paediatric patients in Turkey. J Glob Antimicrob Resist 2017;11:140-144. https://doi. org/10.1016/j.jgar.2017.07.018

3. Hsu AJ, Tamma PD. Treatment of multidrug-resistant gram-negative infections in children. Clin Infect Dis 2014;58:1439-1448. https://doi.org/10.1093/cid/ciu069

4. Woodford N, Turton JF, Livermore DM. Multiresistant gram-negative bacteria: the role of high-risk clones in the dissemination of antibiotic resistance. FEMS Microbiol Rev 2011;35:736-755. https://doi.org/10.1111/ j.1574-6976.2011.00268.x 
5. Thiébaut AC, Arlet G, Andremont A, et al. Variability of intestinal colonization with third-generation cephalosporin-resistant Enterobacteriaceae and antibiotic use in intensive care units. J Antimicrob Chemother 2012;67:1525-1536. https://doi. org/10.1093/jac/dks072

6. Celiloğlu C, Tolunay O, Çelik T, Sucu A, Yurtçu E, Celik U. Çocuk yoğun bakım ünitesindeki hastane enfeksiyonlarının değerlendirilmesi. J Pediatr Inf 2017;11:129-134. https://doi.org/10.5578/ced.64028

7. Jordan Garcia I, Esteban Torné E, Bustinza Arriortua $A$, et al. Trends in nosocomial infections and multidrugresistant microorganisms in Spanish pediatric intensive care units. Enferm Infecc Microbiol Clin 2016;34:286292. https://doi.org/10.1016/j.eimc.2015.07.010

8. World Health Organization. 2017. Antimicrobial resistance-global report on surveillance. Available at www.who.int/drugresistance/documents/ surveillancereport/en. Accessed January 02, 2020

9. Araujo da Silva AR, Henriques CT, Werneck LS. Health care associated infections by multidrug resistant organisms in pediatric intensive care: analysis of four years. Int J Infect Control 2014;10:1-7. https://dio. org/10.3396/ijic.v10i3.12287

10. Karam G, Chastre J, Wilcox MH, Vincent JL. Antibiotic strategies in the era of multidrug resistance. Crit Care 2016;20:136. https://doi.org/10.1186/s13054-0161320-7

11. Sehulster L, Chinn RYW, Arduino MJ, et al. Guidelines for environmental infection control in health-care facilities. Recommendations of CDC and the healthcare infection Control Practices Advisory Committee (HICPAC). Available at: http://www.cdc.gov/ infectioncontrol/guidelines/environmental/index.html. Accessed July 2019

12. Winn W, Allen S, Janda W, et al. Koneman's Color Atlas and Textbook of Diagnostic Microbiology. 6th ed. Philadelphia: Lippincott Williams and Wilkins, 2006.

13. Russell CJ, Mack WJ, Schrager SM, Wu S. Care variations and outcomes for children hospitalized with bacterial tracheostomy associated respiratory infections. Hosp Pediatr 2017;7:16-23. https://doi. org/10.1542/hpeds.2016-0104

14. CDC/NHSN Surveillance Definition of HealthcareAssociated Infection and Criteria for Specific Types of Infections in the Acute Care Setting, Available from: http://www.cdc.gov/nhsn/PDFs/ pscManual/17pscNosInfDef_current.pdf. Accessed January 2013

15. Magiorakos AP, Srinivasan A, Carey RB, et al. Multidrug-resistant, extensively drug-resistant and pandrug-resistant bacteria: an international expert proposal for interim standard definitions for acquired resistance. Clin Microbiol Infect 2012;18:268-281. https://doi.org/10.1111/j.1469-0691.2011.03570.x
16. Atay $G$, Kara $M$, Sütçü $M$, et al. Resistant gramnegative infections in a pediatric intensive care unit: a retrospective study in a tertiary care center. Turk Pediatri Ars 2019;54:105-112. https://doi.org/10.14744/ TurkPediatriArs.2019.00086

17. El Nawawy A, Ashraf GA, Antonios MAM, Meheissen MA, El Alfy MMR. Incidence of multidrug-resistant organism among children admitted to pediatric intensive care unit in a developing country. Microb Drug Resist 2018;24:1198-1206. https://doi.org/10.1089/ mdr.2017.0414

18. Naldan ME, Coşkun MV, Ünal O, Karaşahin Ö, Vural MK. Yoğun bakım kliniklerinde yatan hastalardan izole edilen gram negatif basillerin değerlendirilmesi. J Turk Soc Intens Care 2017;15:117-123. https://doi. org/10.4274/tybd.15238

19. Maechler F, Peña Diaz LA, Schröder C, Geffers C, Behnke M, Gastmeier P. Prevalence of carbapenemresistant organisms and other Gram-negative MDRO in German ICUs: first results from the national nosocomial infection surveillance system (KISS). Infection 2015;43:163-168. https://doi.org/10.1007/ s15010-014-0701-6

20. Russell CJ, Thurm C, Hall M, Simon TD, Neely MN, Berry JG. Risk factors for hospitalizations due to bacterial respiratory tract infections after tracheotomy. Pediatr Pulmonol 2018;53:349-357. https://doi. org/10.1002/ppul.23938

21. Russell CJ, Mack WJ, Schrager SM, Wu S. Care variations and outcomes for children hospitalized with bacterial tracheostomy-associated respiratory infections. Hosp Pediatr 2017;7:16-23. https://doi. org/10.1542/hpeds.2016-0104

22. Routsi C, Pratikaki M, Platsouka E, et al. Risk factors for carbapenem-resistant gram-negative bacteremia in intensive care unit patients. Intensive Care Med 2013;39:1253-1261. https://doi.org/10.1007/s00134013-2914-z

Teşekkür: $\mathrm{Bu}$ çalışmaya katkılarından dolayı hocalarımız Prof. Dr. Murat Anıl ve Prof. Dr. Ayşe Berna Anıl'a, D.D.H Mikrobiyoloji uzmanı Dr. Havva Kaya'ya, Enfeksiyon Kontrol Komitesi hemşiresi Eylem Menemencioğlu ve D.D.H çocuk yoğun bakım ünitesi hemşirelerine teşekkürü borç biliriz.

Etik onayı: $\mathrm{Bu}$ çalışma için etik kurul onayı, İzmir Demokrasi Üniversitesi Girişimsel Olmayan Klinik Araştırmalar Etik Kurulu'ndan alınmıştır (tarih/karar no:2019/06-02).

\section{Yazarların makaleye olan katkıları}

F.K. çalışmanın ana fikrini ve hipotezini kurgulamıştır. F.K ve D.Ş.O teoriyi geliştirmiş 
ve materyel metod bölümünü düzenlemişlerdir. Sonuçlar kısmındaki verilerin değerlendirmesini F.K yapmıştır. Makalenin tartışma bölümü F.K tarafından yazılmış, D.Ş.O gözden geçirip gerekli düzeltmeleri yapmış ve onaylamıştır. Ayrıca tüm yazarlar çalışmanın tamamını tartışmış ve son halini onaylamıştır. 